\title{
PREDICTING THE CLEAVAGE SITES OF MULTIPLE PROTEASES FAMILIES ON RICE ALPHA AMYLASE ISOZYME 3D SEQUENCE
}

\author{
Ayu Oshin Yap Sinaga ${ }^{1}$, David Septian Sumanto Marpaung ${ }^{2}$ \\ ${ }^{1}$ Department of Biology, Institut Teknologi Sumatera (ITERA); \\ ${ }^{2}$ Department of Biosystems Engineering, Institut Teknologi Sumatera (ITERA) \\ Corresponding author email: oshin.yap@bi.itera.ac.id
}

\begin{abstract}
Proteases is a proteolytic enzyme that often determined the crucial process in degradation pathway occurred in all of organisms. Prediction of novel protease is important action to design the protease inhibitor. In the secretion of rice $\alpha$ Amy 3 protein in outside cells will be followed by secretion of recombinant protein target and proteolytic enzymes together, which means potentially also degraded the recombinant protein target In this study, the proteases was detected in rice $\alpha$ AMY $3 \mathrm{D}$ protein sequences. Our study resulted the 3 major proteases appeared in rice $\alpha \mathrm{AMY} 3 \mathrm{D}$ protein sequences, they were cysteine proteases, serine proteases and metalloproteases. Based on the literature, such proteases also appeared in rice suspension cells. Design the inhibitor for such proteases will be suggested for reduction of proteases level.
\end{abstract}

Keywords: proteases, in silico, PROSPER, rice cells.

\section{INTRODUCTION}

Proteases is the machinery enzyme which able to degrade protein in all of organisms. Many of proteases have their own biochemical and regulatory characteristics. Proteolytic enzymes, or proteases, role as overall metabolic controller and key point in transduction pathways by directing the activation or hydrolysis of proteins implicated in regulatory process, or by contributing to the eliminate the misfolded proteins and the selective recycling of amino acids from short-lived proteins (Mandal et al. 2016). In plant, as metabolic controller, they plays important role during development stage and stress condition. The finding of proteases for the initiation and completion of animal apoptosis, and caspase enzymatic activities in plant cell extracts, is linked the plant proteases to program cell death (Cai and Gallois 2015). Therefore, the proteases study in plant gain interest, due to it will affect the yield reduction in plant production and the diversity in the nature.

Proteolysis degradation is one of the challenges for optimized accumulation of recombinant proteins in the plant cell system. The reduction of recombinant protein levels in plant cell cultures has been described as a proteases effect and affect the plant metabolic pathway
(Yusibov et al. 2016). Other candidate biopharmaceuticals, such as, human serum albumin (Sun et al. 2011) and cytokines (Sirko et al. 2011) also showed the proteolytic processing when they are produced in plant cells. The identification of proteases that are responsible for the degradation of a given recombinant protein is the new challenges, due to the difficulties to find the proteolytic enzymes candidate among several hundred proteolytic enzymes in plant (SimovaStoilova et al. 2010). Identification of unknown proteases degraded the recombinant protein targeted become important issue, in order to tackle the reduction of recombinant protein yield.

The finding of several recombinant protein degradations in its host, led many people to find the specific type of proteases, in order to know the best treatment for prevent or reduce the proteases level in the host. There are many methods applied to identify the proteases in plant cells, including mass spectrometry technique (Giansanti et al. 2016) and in silico methods (Song et al. 2012). in silico method has known as a useful alternative approach to provide good insights into complex proteases interaction. Besides, computational tools will reduce the cost in experiment for identify the proteases. Therefore, in this study, the bioinformatics approaches will be applied in order to find 
the candidate of proteolytic enzymes in plant. The aim of this study was to predict the proteases appeared in $\alpha$-amylase ( $\alpha \mathrm{AMY}$ ) 3D sequences, one of common protein secreted along with recombinant protein in rice suspension cell systems.

\section{METHOD}

\section{Data Collection}

The rice $\alpha \mathrm{AMY} 3 \mathrm{D}$ protein sequences was obtained from Uniprot (entry name: AMY3D_ORYSJ and the accession number: P27933). The total $38 \mathrm{kDa}$ sequences of rice $\alpha A M Y 3 D$ showed in Figure 1.

\section{Proteases Prediction}

The proteases prediction conducted by using PROSPER (Song et al. 2012). PROSPER is a prediction tool for in silico prediction of protease substrates and their cleavage sites based on the webserver, for twenty-four different protease types, covering four major protease familiesAspartic (A), Cysteine (C), Metallo (M) and Serine $(\mathrm{S})$. The protein sequence of rice $\alpha$ AMY $3 \mathrm{D}$ was input in the webserver. The notification of prediction results will be sent to email soon after the protein sequences insertion to webserver. The computer specification to run this software are Intel Celeron CPU N3050 @ 1.60GHz, RAM 2 GB, 64-bit Operating System and x64-based processor.

\section{Data Analysis}

The characterization of predicted proteases data was conducted in cleavage sites of multiple protease families. The data was then analyzed by descriptive analysis, and compared with the literature available from scientific journal using google, a search engine.

$\begin{array}{rrrrr}10 & 20 & 30 & 40 & 50 \\ \text { MKNTSSLCLL } & \text { LLVVLCSLTC } & \text { NSGQAQVLFQ } & \text { GFNWESWKQQ } & \text { GGWYNMLKGQ } \\ 60 & 70 & 80 & 90 & 100 \\ \text { VDDIAKAGVT } & \text { HVWLPPPSHS } & \text { VAPQGYMPGR } & \text { LYDLDASKYG } & \text { TAAELKSLIA } \\ 110 & 120 & 130 & 140 & 150 \\ \text { AFHGKGVQCV } & \text { ADVVINHRCA } & \text { EKKDARGVY } & \text { VFEGGTPDDR } & \text { LDWGPGMICS } \\ 160 & 170 & 180 & 190 & 200 \\ \text { DDTQYSDGTG } & \text { HRDTGEGFGA } & \text { APDIDHLNPR } & \text { VQRELTDWLN } & \text { WLKSDVGFDG } \\ 210 & 220 & 230 & 240 & 250 \\ \text { WRLDFAKGYS } & \text { TDIAKMYVES } & \text { CKPGFVVAEI } & \text { WINSLSYNGDG } & \text { KPAANQDQGR } \\ 260 & 270 & 280 & 290 & 300 \\ \text { QELVNWVNAV } & \text { GGPAMTFDFT } & \text { TKGLLQAGVQ } & \text { GELWRLRDGN } & \text { GKAAGMIGWL } \\ 310 & 320 & 330 & 340 & 350 \\ \text { PEKAVTFVDN } & \text { HDTGSTQKLW } & \text { PFPSDKVMQG } & \text { YAYILTHPGV PCIFYDHMFD } \\ 360 & 370 & 380 & 390 & 400 \\ \text { WNLKQEITAL } & \text { AAIRERNGIN } & \text { AGSKLRIVVA } & \text { DADAYVAWV EKVMVKIGTR } \\ 410 & 420 & 430 & & \end{array}$

Figure 1. The protein sequences of rice $\alpha \mathrm{AMY} 3 \mathrm{D}$ 


\section{RESULTS AND DISCUSSION}

The current major rice suspension system uses a highly inducible $\alpha$-Amylase promoter to control protein expression. The $\alpha$ Amy 3 promoter gene was characterized as the more responsive promoter to sugar starvation (Hong et al. 2012). However, the sugar starvation condition often resulted in secreted of proteolytic enzymes (Kim et al. 2008). The physical changes also can occurred in certain condition in the plant (Marpaung et al. 2019). The secretion of $\alpha$ Amy 3 protein in outside cells will be followed by secretion of recombinant protein target and proteolytic enzymes together. In other words, there are several proteases targeting to $\alpha$ Amy 3 protein will also appeared in the medium together with recombinant protein target, which possibly to degrade the recombinant protein. Identification of type of proteases targeting to $\alpha$ Amy 3 protein will allow knowing any possible proteases will attack the recombinant protein target in the medium of rice suspension cells. Therefore, understanding the type of proteases will allow the best treatment for yield reduction in rice suspension cells.

In this study, the proteases cleavage site was predicted using PROSPER in the $38 \mathrm{KDa}$ sequences. Based on the output, there are several proteases cleavage the $\alpha$ AMY 3D sites (Fig 2.). There are 82 total predicted proteases will appeared in aAMY 3D sequences, among the superfamilies proteases. The serine proteases (38 unit) were the most appeared in the aAMY 3D sequences (Fig 3), followed by metalloproteases (31 unit) and cysteine proteases ( 7 unit) (Table 1$)$. The studies on serine protease inhibitors for inhibition the chymotrypsin and trypsinlike proteases become focused recently, due to the majority of protease activity in plant cells was from serine proteases (Pillay et al. 2014). Serine inhibitor has been used to tackle the unwanted serine proteases in transformed rice cell suspension cultures (Kim et al. 2007). In that study, overexpressing the chymotrypsin and trypsin inhibitor, a type of serine proteases inhibitor, resulted on reduction of protease activity approximately $23 \%$ compare to nontransformed cells. The metalloproteases also become concern in plant research. The matrix metalloproteinases in tomato has been known as cell death controller (Zimmermann et al. 2016).

The proteases activities in rice suspension cultured cells in medium during sucrose starvation has been characterized, and found the metalloprotease is one of protease secreted to the rice medium (Ho et al. 2008). Meanwhile, the major of extracellular protein secreted to medium was cysteine protease via sucrose starvation (Kim et al. 2008). Protease inhibitor cocktail and overexpression of proteases inhibitor could be the solution in order to reduce the unwanted proteases in rice suspension cells.

Table 1. Comparison Between Predicted Proteases and Experimental Identified in $\alpha A m y 3 D$ sequences

\begin{tabular}{|c|c|c|c|}
\hline $\begin{array}{c}\text { Type of } \\
\text { Predicted } \\
\text { Protease }\end{array}$ & $\begin{array}{c}\text { Prediction } \\
\text { Cleavage } \\
\text { Sites } \\
\text { (unit) }\end{array}$ & $\begin{array}{c}\text { Experiment on } \\
\text { Proteases } \\
\text { Identification }\end{array}$ & Refference \\
\hline $\begin{array}{c}\text { Cysteine } \\
\text { protease }\end{array}$ & 7 & $\begin{array}{c}\text { Cysteine and } \\
\text { Endopeptidase }\end{array}$ & $\begin{array}{c}\text { Kim et al., } \\
2008\end{array}$ \\
\hline $\begin{array}{c}\text { Metallopr } \\
\text { otease }\end{array}$ & 31 & $\begin{array}{c}60-70 \mathrm{KDa} \\
\text { and 110 KDa } \\
\text { Metallo } \\
\text { Proteases }\end{array}$ & $\begin{array}{c}\text { Ho et al., } \\
2008\end{array}$ \\
\hline $\begin{array}{c}\text { Serine } \\
\text { protease }\end{array}$ & 38 & $\begin{array}{c}\text { Chemotrypsin } \\
\text { and Trypsin }\end{array}$ & $\begin{array}{c}\text { Kim et al., } \\
2007\end{array}$ \\
\hline
\end{tabular}

\section{CONCLUSION}

Designing novel inhibitor as controller for regulate the protease function, prediction of putative protease substrates is a critical action. In this study, the 3 major proteases, including cysteine protease, serine protease and metalloprotease have been predicted appeared on $\alpha$ Amy3D protein sequences. 


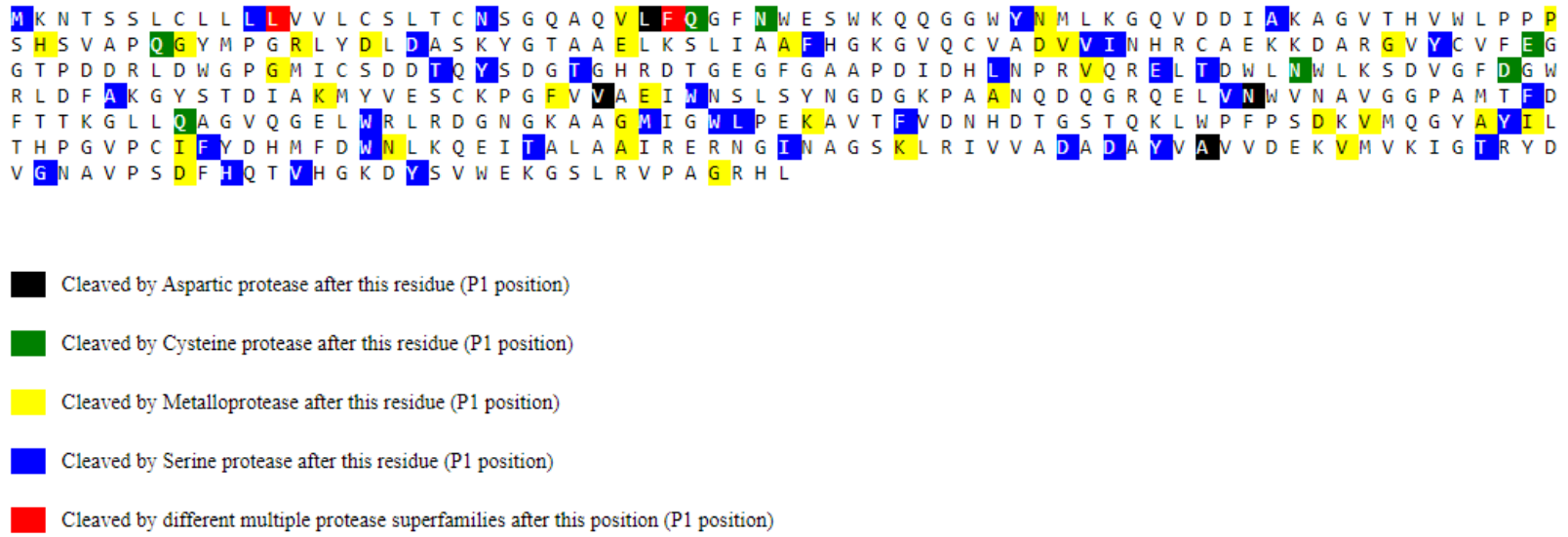

Figure 2. Predicted cleavage sites of protease in $\alpha \mathrm{AMY} 3 \mathrm{D}$ sequences

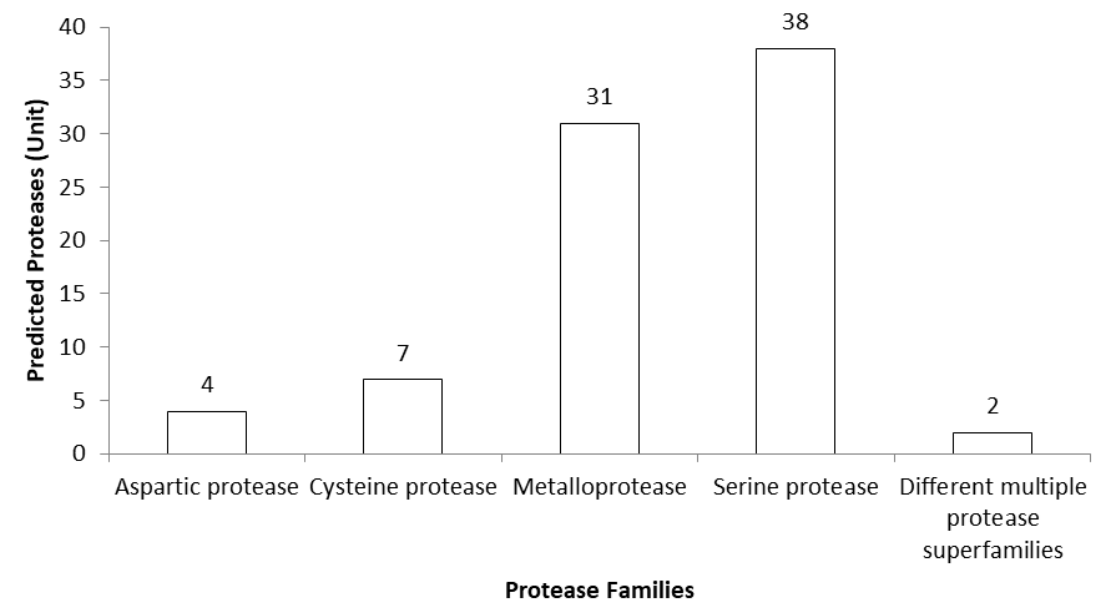

Figure 3. Comparison the amount of proteases appeared in $\alpha$ AMY 3D sequences

The secreted $\alpha \mathrm{Amy} 3 \mathrm{D}$ protein in rice suspension cells medium possibly bring such proteases, and able to degrade the recombinant protein target. Our study suggest for further treatment, such as design the proteases inhibitor, either in cocktail form or expressing the gene inside the cells.

\section{REFERENCES}

Cai Y-m, Gallois P (2015) Programmed Cell Death Regulation by Plant Proteases with Caspase-Like Activity. In: Gunawardena AN, McCabe PF (eds) Plant Programmed Cell Death. Springer International Publishing, Cham, pp 191202. doi:10.1007/978-3-319-21033-9_8
Giansanti P, Tsiatsiani L, Low TY, Heck AJ (2016) Six alternative proteases for mass spectrometry-based proteomics beyond trypsin. Nature protocols 11 (5):993

Ho SL, Lin M. S, H.H. L (2008) Characterization of the Proteases Activities in Rice Suspension Cultured Cells and Medium during Sucrose Starvation. Crop, Environment \& Bioinformatics 5 (0):237-247

Hong Y-F, Ho T-HD, Wu C-F, Ho S-L, Yeh R-H, Lu C-A, Chen P-W, Yu L-C, Chao A, Yu S-M (2012) Convergent Starvation Signals and Hormone Crosstalk in Regulating Nutrient Mobilization upon Germination in Cereals. The Plant Cell 24 (7):28572873. doi:10.1105/tpc.112.097741

Kim N-S, Kim T-G, Kim O-H, Ko E-M, Jang Y-S, Jung E-S, Kwon T-H, Yang M-S (2008) Improvement of recombinant hGM-CSF production by suppression of 
cysteine proteinase gene expression using RNA interference in a transgenic rice culture. Plant Molecular Biology 68 (3):263. doi:10.1007/s11103-008-9367-8

Kim T-G, Kim H-M, Lee H-J, Shin Y-J, Kwon T-H, Lee N-J, Jang Y-S, Yang M-S (2007) Reduced protease activity in transformed rice cell suspension cultures expressing a proteinase inhibitor. Protein Expression and Purification 53 (2):270274. doi:https://doi.org/10.1016/j.pep. 2007.01.005

Mandal MK, Ahvari H, Schillberg S, Schiermeyer A (2016) Tackling unwanted proteolysis in plant production hosts used for molecular farming. Frontiers in plant science 7:267

Marpaung DSS, Fil'aini R, Fahrani AC, Cahyani D, Sinaga AOY (2019) Physical Changes Of Andaliman (Zanthoxylum Acanthopodium Dc.) In Packaging During Low-Temperature Storage. 2019 13(2):6.doi:10.21107/agrointek.v13i2.55 43

Pillay P, Schlüter U, van Wyk S, Kunert KJ, Vorster BJ (2014) Proteolysis of recombinant proteins in bioengineered plant cells. Bioengineered 5 (1):15-20. doi:10.4161/bioe. 25158

Simova-Stoilova L, Vaseva I, Grigorova B, Demirevska K, Feller U (2010) Proteolytic activity and cysteine protease expression in wheat leaves under severe soil drought and recovery. Plant Physiology and Biochemistry 48 (23):200-206

Sirko A, Vaněk T, Góra-Sochacka A, Redkiewicz P (2011) Recombinant Cytokines from Plants. International Journal of Molecular Sciences 12 (6):3536-3552

Song J, Tan H, Perry AJ, Akutsu T, Webb GI, Whisstock JC, Pike RN (2012) PROSPER: An Integrated Feature-Based Tool for Predicting Protease Substrate Cleavage Sites. PLOS ONE 7 (11):e50300.

doi:10.1371/journal.pone.0050300

Sun Q-Y, Ding L-W, Lomonossoff GP, Sun YB, Luo M, Li C-Q, Jiang L, Xu Z-F (2011) Improved expression and purification of recombinant human serum albumin from transgenic tobacco suspension culture. Journal of
Biotechnology $155 \quad$ (2):164-172. doi:https://doi.org/10.1016/j.jbiotec.2011 .06 .033

Yusibov V, Kushnir N, Streatfield SJ (2016) Antibody Production in Plants and Green Algae. Annual Review of Plant Biology 67 (1):669-701. doi:10.1146/annurevarplant-043015-111812

Zimmermann D, Gomez-Barrera JA, Pasule C, Brack-Frick UB, Sieferer E, Nicholson TM, Pfannstiel J, Stintzi A, Schaller A (2016) Cell Death Control by Matrix Metalloproteinases. Plant Physiology 171(2): 1456-1469. doi:10.1104/pp.16.00513 